\title{
International Approaches to Spent Fuel Management: Challenges and Opportunities
}

\author{
Andrew Newman ${ }^{1, *}$, Thomas Isaacs ${ }^{1}$, Alina Constantin ${ }^{2}$ \\ ${ }^{1}$ Nuclear Threat Initiative, 1747 Pennsylvania Avenue, NW, Washington, DC 20006, USA \\ ${ }^{2}$ Institute for Nuclear Research, Campului Str., Nr. 1, POB 78, 115400, Mioveni, Romania
}

Copyright $\mathrm{O} 2016$ by authors, all rights reserved. Authors agree that this article remains permanently open access under the terms of the Creative Commons Attribution License 4.0 International License

\begin{abstract}
Despite well-developed repository programs in several countries, the vast majority of states continue to struggle developing and implementing plans to dispose of spent fuel and high level waste produced by nuclear power programs. The lack of spent fuel management options strains the credibility of the nuclear community and undercuts public and political acceptance for current and future nuclear activities. It is unethical, irresponsible and ultimately unsustainable to push the problem onto future generations. It is also a proliferation and security issue. Cooperative networks and regional frameworks for spent fuel storage and disposal could be a productive way to address these problems, particularly in Asia where the need is urgent and growing, and elsewhere. Such partnerships can enhance regional transparency and flexibility as well as improving global security and fortifying nonproliferation. However, the possibility of multinational options should not be used as an excuse for countries to neglect domestic responsibilities; all countries must have a national spent fuel management program. Conversely, national programs should not oppose concerted exploration of multinational approaches.
\end{abstract}

Keywords Spent Fuel Disposal Challenges, Cooperative Approaches in Spent Fuel Disposal, Multinational Radioactive Waste Repository, Nonproliferation

\section{Introduction}

Thirty-one countries plus Taiwan operate nuclear power plants; sensitive fuel cycle capabilities are concentrated in fewer than ten of those.

Globally, reactors generate about 10,500 metric tons of spent fuel each year. More than 270,000 metric tons of spent fuel is held in storage worldwide, most at reactor sites. About 90 percent of that spent fuel is in storage pools, the remainder is in dry casks.

In addition, the amount of separated plutonium continues to grow internationally because it cannot be consumed anywhere near as quickly as it is produced; decisions about reprocessing are often disconnected from use of the recovered products.

Despite the well-developed repository programs in Sweden, Finland and France, and encouraging progress towards siting national repositories in the UK and Canada, political and technical difficulties have so far delayed and, in many cases, prevented the construction and operation of any commercial repositories. As a result,the vast majority of countries continue to struggle with developing and implementing plans to safely and securely dispose of the waste produced by nuclear power programs.

The lack of spent fuel management options strains the credibility of the nuclear community and undercuts public and political acceptance for all nuclear activities. Continuing along this path is ultimately unsustainable. Meanwhile, spent fuel continues to accumulate in cooling pools with limited storage capacity. On-site dry cask storage is a mid-term but still temporary solution, and reprocessing/recycling still generates significant waste streams that require permanent disposal.

Both storage and disposal programs are needed: storage provides the interim solution until the repository is operating; the repository program provides a permanent solution and the necessary public and political assurance that the storage site will not become a de facto repository.

\section{Spent Fuel Disposal Challenges}

Finding a suitable host site for a spent fuel repository is a complex and difficult undertaking. The challenges can be grouped into four broad areas.

Geological: Geological disposal is the internationally accepted strategy for permanently isolating spent nuclear fuel and high-level waste. However, not all countries have the appropriate geological conditions for such disposal and some have only a limited amount of real estate potentially available for this purpose. For example, seismic activity in 
Japan makes many parts of the country unsuitable for spent fuel/high level waste disposal compared to the geological stability and diversity (e.g. salt, basalt, tuff, granite, clay/shale and crystalline rock) in different parts of the United States.

Political/Social: Securing public acceptance is the most difficult task for any authority attempting to site a repository. For example, despite the geological diversity described above, in 2010 the Obama Administration declared the Yucca Mountain site unworkable and eliminated all funding for repository licensing and construction. [1] This, despite the fact that the federal government had spent more than $\$ 11$ billion on siting activities up to that point. As a result, the United States has no effective program for managing and ultimately disposing of the spent fuel and high-level radioactive waste produced by the nation's nuclear power plants. Thirty years after the Nuclear Waste Policy Act was signed into law mandating the operation of a geologic repository by January 31, 1998, there is no active U.S. repository program though there is recent movement to restart it. Years of work and billions of dollars have proven unsuccessful to date in meeting the nation's spent fuel management and disposal needs. [2, 3]

Financial: About half of the countries currently operating nuclear power plants have fewer than five reactors. This means they do not accumulate spent fuel very quickly. It also means that spent fuel management becomes proportionately a very expensive component of their nuclear programs. Access to a disposal pathway that limits responsibility for spent fuel management may make more sense financially and, in most cases, politically. The United Arab Emirates, which has contracted with a Korea Electric Power Corporation-led consortium for four APR-1400 reactors that are expected to begin operation by 2020 , is already thinking along these lines. While the Swedish Nuclear Fuel and Waste Management Company (SKB) is helping the government to determine the feasibility of a national geologic repository, director of radiation safety at the UAE Federal Authority for Nuclear Regulation Dr. John Loy has observed: "Options that may be considered for the National Strategy on Nuclear Waste Disposal would be either regional or international repositories operating in different countries."' $[4,5]$

Security/Nonproliferation: Spent nuclear fuel needs to be stored for extended periods of time until the fuel has cooled sufficiently before repositories can begin accepting it perhaps 40 years or more.[6] In addition, increasingly high burn-up fuel and large dry storage canisters make moving spent fuel stored in such canisters problematic in the short to medium term because the allowable thermal and radiation limits for transportation can be substantially lower than the limits for storage, requiring an extended period of aging before the canisters have cooled down enough to be moved. In most cases it will be decades before repositories are open and able to accept waste in sufficient quantities to begin to significantly draw down the inventory. The longer spent fuel is stored, the less self-protecting it becomes as the strongly radiating shorter lived isotopes that provide the protection continue to decay, and thus as it becomes less radioactive, the greater security risk it presents. In addition, lack of disposal options has led some countries to conclude that recycling spent fuel for use as mixed oxide (MOX) fuel is an alternative to long-term storage/disposal, at least in the short to medium-term. However, this does not obviate the need for a repository and reprocessing can produce separated plutonium that might be acquired by non-state actors for use in nuclear explosive devices or diverted into illicit state-run nuclear weapons programs.

\section{Cooperative Approaches in Theory and Practice}

The International Atomic Energy Agency has identified three broad scenarios for developing multinational repositories. [7]

\section{Cooperation}

- several states with small but developed nuclear programs agree to use a shared repository in an appropriate volunteer host state

- states with small amounts of radioactive waste cooperate to ensure one of their number acquires the necessary technology and institutional structures

\section{Add-on}

- a host state offers to expand its existing national repository to accept spent fuel/high level waste from other states

\section{International/Supranational}

- ahost state or states cede control of a repository or network of repositories to an international body.

However, efforts to operationalize multinational radioactive waste storage/disposal have so far proved unsuccessful. For example, in 2002 Kazatomprom expressed interest in importing low and intermediate level radioactive waste to Kazakhstan which it would temporarily store in abandoned uranium mines until a disposal facility was built in Aktau. Strong opposition from environmental groups and civil society combined with the 2006 signing of the Central Asian Nuclear-Weapon Free Zone (CANWFZ), which prohibits import of any foreign radioactive waste into the region, effectively killed the plan.[8] In the mid-1990s, the President of the Marshall Islands proposed leasing a contaminated island for nuclear waste disposal and US Fuel and Security, in cooperation with MINATOM, proposed storing spent fuel and excess plutonium on Wake Island and later Palmyra Island. Both proposals were shelved as a result of strong domestic and regional opposition. There have also been several false starts in Australia, including an idea in the late 1970s for regional spent fuel storage on Christmas Island (an Australian territory in the Indian Ocean) and, more controversially, the aborted development of a concept by the UK-Canadian-Swiss company Pangea Resources in the late 1990s to locate an international repository in Western and 
Southern Australia.[9] But this does not mean that collaborative work is non-existent.

Spent fuel management in many European nations is considered a 'European challenge.' This is particularly true of those with relatively small nuclear power programs although several countries with advanced repository programs have expressed some concern that any focus on regional solutions could undermine domestic support for their own national repository programs. But for the majority, this has nurtured collaboration. From 2003 to 2008, the European Commission funded pilot studies on the feasibility of shared regional storage facilities and geological repositories in Europe and options for the establishment of a European Repository Development Organization (ERDO). A working group - which has included representatives from Austria, Bulgaria, Denmark, Ireland, Italy, Lithuania, Netherlands, Poland, Romania, Slovakia and Slovenia since its creation in 2009 - has been established to build consensus about how to proceed with cooperative approaches to spent fuel management and lay the ground work for the establishment of the ERDO. While the sensitive issue of siting has been deliberately postponed until more work has been completed on both geological screening and trust-building, the working group serves as an important forum to exchange information and build national capacity.[10] On July 19, 2011 the European Council adopted a legally binding and enforceable European Commission proposal which read in part: "Radioactive waste shall be disposed of in the Member State in which it was generated, unless agreements are concluded between Member States to use disposal facilities in one of them."[11] It should be noted that the complexities of managing liability and other legal arrangements are minimized to a significant extent in the EU and Euratom due to an existing common understanding of basic concepts and an agreed regulatory framework, making the application of the EC example elsewhere complicated.

\section{The Benefits of Cooperation}

Cooperative approaches to spent fuel management offer a number of potential benefits. They can: promote economies of scale; enable spent fuel to be consolidated more quickly at storage facilities and perhaps allow earlier access to disposal facilities; lower environmental impacts; provide a wider choice of geological conditions; present a business opportunity for the host country; enhance regional transparency and confidence; enable the integration of engineering, hard science and social science research; create 'breathing room' (i.e. interim storage) while disposal options are developed; and demonstrate safe operation which helps build public trust.

Cooperative disposal may also increase global security in several ways. First, by reducing stocks of spent fuel in countries whose national repository plans are uncertain at best and by consolidating spent fuel from many locations at a few safeguarded facilities with high levels of security? It is true that multinational repositories, as opposed to national repositories, may require more spent fuel shipments over greater distances, increasing cost and security risk. But if managed properly, the relatively modest increases in short-term costs and risks are outweighed by the longer-term costs and risks posed by continued national on-site storage and/or disposal. Second, the non-existent back end commercial market presents an opportunity for leveraging the provision of a spent fuel disposal pathway in return for a commitment not to pursue sensitive fuel capabilities such as enrichment and reprocessing. Viewing the consolidation and minimization of spent fuel stockpiles as a contribution to national security would be a powerful motivator - and has driven US and Russian threat reduction programs converting research reactors using HEU fuel to LEU and removing HEU from as many sites and countries as possible - but so far this argument has not been embraced by policy-makers.

The creation of cooperative networks and regional frameworks for storage and disposal would be a productive way to pursue spent fuel management, particularly in Japan, South Korea and Taiwan where storage space shortages in spent fuel pools are becoming acute. While a new organization would need to be established in Asia, the Gulf Cooperation Council (which has already cooperated on regional nuclear energy studies) and the African Commission on Nuclear Energy (AFCONE) could form the basis of such networks amongst nuclear newcomers in the Middle East and Africa. Regional approaches could present a 'win-win-win' path forward by allowing for the safe and effective expansion of nuclear power while simultaneously reducing security and non-proliferation concerns and helping to solve the spent fuel/high level waste dilemma. However, sensitivity to the mutual impacts of national and multinational initiatives is vital. The possibility of multinational options arising should not be used as an excuse for countries to neglect domestic responsibilities; all countries must have a vibrant national program for spent fuel management. By the same token, national programs should not oppose multinational approaches.

\section{Toward Solutions}

For waste management programs to have best chance of success, it is extremely important to recognize that a national problem exists and for that recognition to translate into a national commitment to provide a solution in a reasonable amount of time. As the Blue Ribbon Commission on America's Nuclear Future (BRC) observed, "This generation has a fundamental ethical obligation to avoid burdening future generations with the entire task of finding a safe permanent solution for managing hazardous nuclear materials they had no part in creating ... while also preserving their energy options."[12] However, trying to find a host community should not be the first step in any national or regional spent fuel management strategy. Indeed, 
premature commitment to a disposal site that later proves deficient can badly damage the credibility of the siting authority as, for example, the US Atomic Energy Commission learnt at Lyons, Kansas in 1971/2 and the South Korean government learnt at Gulup Island in 1995.[13, 14] Site selection should be the eventual outgrowth of an adaptive, staged approach. For regional approaches, there are many types of cooperation short of disposal (e.g. research and development on materials and aging issues common to all parties, joint canister construction, transportation methods) that could be helpful starting points for a dialogue. Achieving a consensus view on the potential benefits and drawbacks of a range of cooperation including consideration of an ultimate multinational facility is a key prerequisite in this process.To be sure, large challenges remain for regional/international storage, disposal and take-back initiatives but the alternative - requiring each nuclear power nation to be self-sufficient at the back-end - is equally challenging. Serious consideration of factors such as security, non-proliferation and cost require the attention of all nuclear nations, particularly countries with small/nascent nuclear programs and limited resources but also countries with large nuclear programs.

Economics is not necessarily one of those challenges. While spent fuel disposal appears to be quite expensive, it is in fact a small fraction of the overall cost of electricity generated by nuclear power - roughly $5 \%$ of the total cost to the consumer. Therefore even significant rises in the cost of waste management do not present a substantial penalty to overall delivered costs, particularly when compared to the potential costs of failure to provide a workable disposal solution. Indeed, geological disposal can, in principle, be both a business venture and a public service. And while no viable business ventures have been initiated yet, the business case for spent fuel management is not the problem. What is needed is a driver (that is, a country or countries and an initiative) to move things forward.

Several developments may serve as game changers for timely waste and broader fuel cycle management solutions in other parts of the world, including:

- $\quad$ the first operating national repository for $H L W / S N F$. This might help to build confidence and overcome political resistance in other parts of the world, although it should be noted that licensing and operation of the U.S. Waste Isolation Pilot Plant (WIPP), the first custom-built deep repository, albeit for what would be considered intermediate level waste from military programs rather than HLW, did not have this effect;

- one or more countries providing a spent fuel take-back service. This could be an effective solution for many nuclear waste generators (from a security, safety technical, financial and social perspective) if an appropriate supplier country was willing to offer this service. Russia is promising to take back spent fuel as part of its nuclear reactor deals with Iran, Turkey and Vietnam. Providing that the country can ensure state-of-the-art competence and facilities, the international community should support any and all such offers, recognizing that they enhance regional and global safety and security. According to a 2007 US-Russian National Academies workshop, "arrangements that would provide assured return of spent nuclear fuel could provide a much more powerful incentive for countries to rely on international nuclear fuel supply than would assured supply of fresh fuel, because assured take-back could mean that countries would not need to incur the cost and uncertainty of trying to establish their own repositories for spent nuclear fuel or nuclear waste'[15];

- one or more countries providing a multinational repository. Like spent fuel take-back, this could be an effective solution for many nuclear waste generators if an appropriate host country was willing to offer this service and recent events in Australia have moved the discussion beyond the purely theoretical. On May 9, 2016 the South Australian Nuclear Fuel Cycle Royal Commission released its findings to the public. The Commission made twelve recommendations to the South Australian (State) Government. Of those, the two most relevant in this context are removing existing prohibitions on the licensing of further processing activities to enable commercial development of multilateral facilities as part of nuclear fuel leasing arrangements and pursuing the opportunity to establish spent fuel and intermediate level waste storage and disposal facilities in South Australia.[16] Following a public consultation period, the South Australian Government will respond to the Commission's report. At the same time, the Federal Government is creating a taskforce to consider the political, legal and regulatory implications of the Commission's report.

\section{Conclusions}

The lack of a repository program strains the credibility of the nuclear community and undercuts public and political acceptance for all nuclear activities. States must recognize that a national waste management problem exists and translate that recognition into a national commitment to provide a solution. Both storage and disposal programs for HLW/SNF are needed.

Many countries facing storage and final disposal siting challenges have an interest in cooperative approaches to spent fuel management. New nuclear entrants with small power programs or plans for such programs have a strong interest in regional approaches to spent fuel storage and disposal given that spent fuel management is proportionately a very expensive component of their nuclear programs. For a potential host, geological disposal can be both a business venture and a public service. Further, this back-end service 
potentially offers opportunities for leveraging the provision of a spent fuel disposal pathway in return for a commitment not to pursue sensitive fuel capabilities such as enrichment and reprocessing. Large challenges remain for multinational storage and disposal initiatives but the alternative - requiring each nuclear power nation to be self-sufficient at the back-end - is equally challenging. At the same time, sensitivity to the mutual impacts of national and multinational initiatives is vital.

A consent-based staged, adaptive approach to spent fuel management is proven global best practice. Trying to find a host community should not be the first step in any national or regional spent fuel management strategy, rather the eventual outgrowth of an adaptive, staged approach. Types of cooperation short of disposal can be helpful starting points for discussions aimed at regional approaches to spent fuel management. There are many technical and non-technical topics that can be studied collaboratively by regional partnerships that avoid the third rail of identifying host sites, including:

- long-term performance of wet and dry storage and long-term performance of spent fuel inside dry casks;

- harmonizing container standards;

- quality assurance across licensable storage, transportation and disposal activities;

- repository safety case development;

- development of a generic profile of the attributes users would want to see in a repository;

- repository monitoring and retrievability.

The establishment of a 'virtual multinational laboratory' to support this agenda would be one way to foster multinational technical and institutional collaboration.

The need for action is urgent but history is littered with precipitate attempts to site spent fuel storage/disposal facilities that have foundered due to technical, political and/or social complications. As a result, the first cooperative steps should be small and concrete with the emphasis on confidence-building.

\section{Disclaimer}

The views expressed in this publication are those of the authors and do not necessarily reflect the Nuclear Threat Initiative, the NTI Board of Directors or institutions with which they are associated.

\section{REFERENCES}

[1] U.S. Department of Energy, Office of Chief Financial Officer, FY 2011 Congressional Budget Request, DOE/CF-0053, Vol. 7, February 2010, 194. Online available from http://www.cfo.doe.gov/budget/11budget/Content/Volume $\%$ 207.pdf
[2] A. Newman. 'An area previously determined to be the best adapted for such purposes': Nevada, Nuclear Waste, and Assembly Joint Resolution 15 of 1975, Journal of Policy History, Vol. 24, No. 3, 2012, 432-465.

[3] United States Nuclear Waste Technical Review Board. Designing a Process for Selecting a Site for a Deep-Mined, Geologic Repository for High-Level Radioactive Waste and Spent Nuclear Fuel, Report to the United States Congress and the Secretary of Energy, November 2015.

[4] World Nuclear Association, "Nuclear Power in the United Arab Emirates," updated July 2016.Online available fromhttp://www.world-nuclear.org/information-library/count ry-profiles/countries-t-z/united-arab-emirates.aspx

[5] M. Awad. 'Decision soon' on UAE nuclear waste. The National, April 30, 2013. Online available from http://www.thenational.ae/news/uae-news/technology/decisi on-soon-on-uae-nuclear-waste

[6] R.B. Firestone et al., Table of Isotopes, Eight Edition, Lawrence Berkeley National Laboratory, University of California, 1998.

[7] IAEA. Developing multinational radioactive waste repositories: Infrastructural framework and scenarios of cooperation, IAEA-TECDOC-1413, October 2004, 16-20. Online available from http://www-pub.iaea.org/MTCD/Publi cations/PDF/te_1413_web.pdf

[8] A. Kirby, "Kazakhstan eyes EU N-waste," BBC News, 21 November 2002. Online available at http://news.bbc.co.uk/2/ hi/science/nature/2488465.stm

[9] IAEA. Developing multinational radioactive waste repositories: Infrastructural framework and scenarios of cooperation, 13.

[10] ERDO Working Group. Working on a shared European solution for radioactive waste, undated. Online available from http://www.erdo-wg.eu/Documents_files/ERDO-WG\%20En .pdf

[11] European Commission Press Release. Nuclear waste: Commission welcomes adoption of radioactive waste directive, 19 July 2011. Online available from http://europa.eu/rapid/pressReleasesAction.do?reference=IP/ 11/906and European Commission Proposal for a Council Directive on the Management of Spent Fuel and Radioactive Waste, COM (2010) 618 Final, Brussels, November 3, 2010. Online available from http://eur-lex.europa.eu/LexUriServ/L exUriServ.do?uri=COM:2010:0618:FIN:EN:PDF

[12] Blue Ribbon Commission on America's Nuclear Future. Report to the Secretary of Energy, January 26, 2012, vi-iv, Online available from: http://brc.gov/sites/default/files/ documents/brc_finalreport_jan2012.pdf

[13] J. S. Walker. An 'Atomic Garbage Dump' for Kansas: The Controversy over the Lyons Radioactive Waste Repository, 1970-1972, Kansas History, 27, Winter 2006-7, 266-285

[14] A. Newman, G. Nagtzaam. Decision-making and Radioactive Waste Disposal (Oxon, OX: Routledge, 2016), p.207

[15] IAEA. Viability of Sharing Facilities for the Disposal of Spent Fuel and Nuclear Waste: An Assessment of Recent Proposals, IAEA-TECDOC-1658, Vienna, September 2011, p.22. Online available from http://www-pub.iaea.org/MTCD/ Publications/PDF/TE-1658_web.pdf 
[16] Nuclear Fuel Cycle Royal Commission, Government of South Australia. Nuclear Fuel Cycle Royal Commission Report,
May 2016. Online available from http://nuclear.yoursay.sa.g ov.au/system/NFCRC_Final_Report_Web.pdf 